Karstenia 46: 25-32, 2006

\title{
Notes on rare species of aphyllophoroid fungi found in Zhiguli Nature Reserve (Samara Region, European Russia)
}

\author{
VERA F. MALYSHEVA
}

MALYSHEVA V.F. 2006: Notes on rare species of aphyllophoroid fungi found in Zhiguli Nature Reserve (Samara Region, European Russia). - Karstenia 46: 25 - 32. Helsinki. ISSN 0453-3402.

Four rare species of aphyllophoroid fungi (Basidiomycota) from Samara Region (European Russia) are described, illustrated and discussed. A new species, Radulomyces arborifer Malysheva \& Zmitr., belonging to the R. molaris complex, is described. The new combination, Basidioradulum syringae (E. Langer) Malysheva \& Zmitr. is proposed. Pilatoporus epileucinus (Pilát) Kotl. \& Pouzar is reported for the first time in Russia. Species keys for raduloid Hyphodermataceae as well as the Pilatoporus ibericus complex are given.

Key words: Aphyllophorales, Basidiomycetes, European Russia, rare species

Vera Malysheva, V.L. Komarov Botanical Institute, Russian Academy of Sciences, Prof. Popov street 2, 197376 St. Petersburg, Russia

\section{Introduction}

The Zhiguli Nature Reserve is situated in the northern part of the Samarskaya Luka peninsula. This area includes the Zhiguli mountains and Shalyga island. The mountain tops are overgrown by steppe-like pine woodlands (Pineta xeroherbosa), whereas the gullies are occupied by shady formations, dominated by Tilia cordata, and intermixed with Quercus robur, Acer platanoides, Ulmus glabra, and U. laevis. Due to its southern situation, the broadleaved forests also include mediterranean floristic elements (Aristolochia clematitis, Laser trilobum, Scutellaria altissima). An isolated position of the Zhiguli island inside a steppe landscape explains the few links with a boreal flora.

As a result, a lot of nemoral species of aphyllophoroid fungi are found in the reserve area. Some taxa are discussed in the present paper.

\section{Materials and methods}

The microscopic characters of fungal specimens were observed in the Karl Zeiss-amplival microscope. The chemical reagents used in the microscopic examination were $5 \%$ solution of potassium hydroxide $(\mathrm{KOH})$, Melzer's reagent (IKI), and Cotton Blue (CB). The measurements were made with oil immersion objective; a total of 30 spores from each specimen were measured. To present a variation of spore size, $5 \%$ of measurements were excluded from each end of the range, and are given in parentheses.

\section{Discussions}

Radulomyces arborifer Malysheva \& Zmitr. sp. nova. - Fig. 1, 2.

Basidiomata annua, resupinata, orbiculata, confluentia. Hymenophorum raduloideum, aculis arboriformis vel coralloideis $0.5-2.5 \mathrm{~mm}$ longis singulatis vel subgrammatis, cremeum vel ad apices ochraceum, cerreum. Systema hypharum monomiticum. Hyphae 1.5-6 $\mu \mathrm{m}$ in diam., medallioniter fibulatae, in tenuitunicatas subhymeniales et crassitunicatas axiales pseudocystidiasque divisae. Cystidia utriformia, 25-50 × 7-8 $\mu \mathrm{m}$. Sporae ellipsoideae ad subcylindraceae, 7-10 $\times$ 5-6.5 $\mu \mathrm{m}$, leniter crassitunicatae, guttulatae, laeves, inamyloideae. 


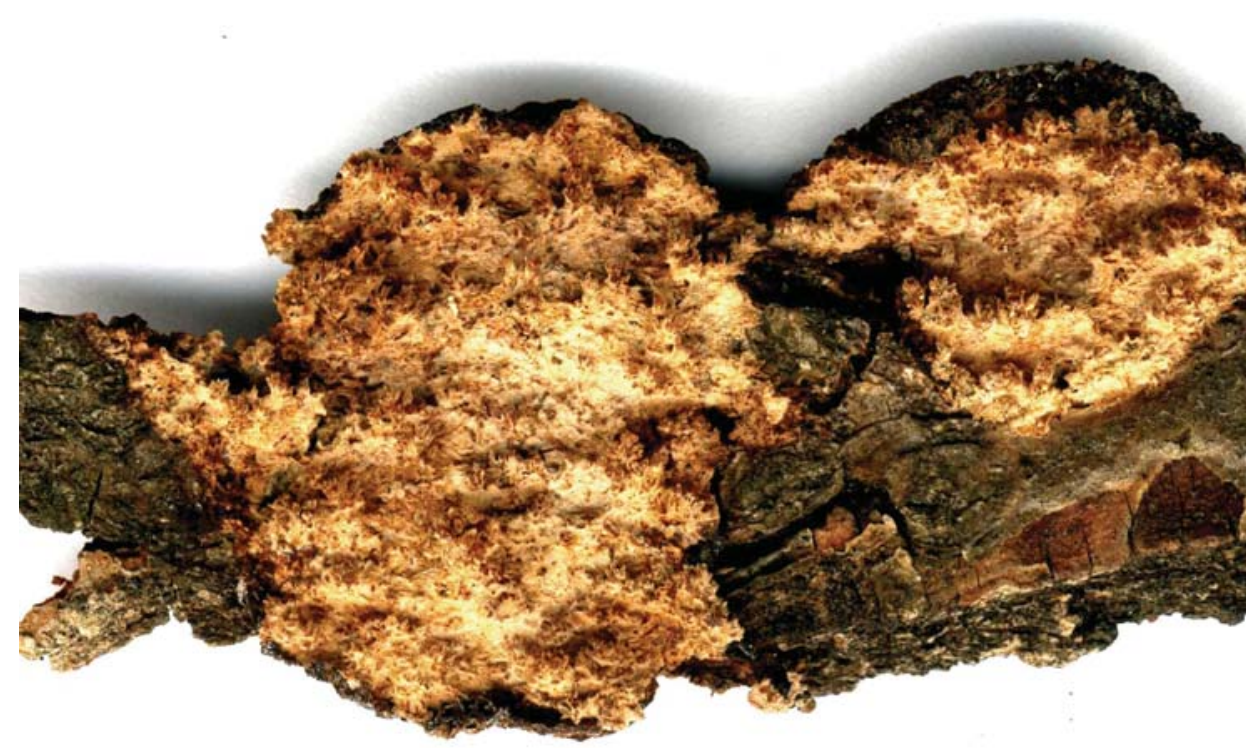

Fig. 1. Radulomyces arborifer Malysheva \& Zmitr. sp. nov. (LE 214706): basidiome.

Holotype: Russia. Samara Region, Zhiguli Nat. Res., fallen log of Tilia cordata in Tilietum aegopodiosum, 24.VIII.2003 V. Malysheva \& I. Zmitrovich (LE 214706).

Basidiomata annual, resupinate, orbicular, later confluent, $1.5-5 \mathrm{~cm}$ wide, $0.5-0.8 \mathrm{~mm}$ thick, with separable, slightly ciliate margin. Hymenophore raduloid, composed of rare dendroid or coralloid aculei $0.5-2.5 \mathrm{~mm}$ long, solitary or arranged in rows near the margin; cream-coloured, the tips of aculei ochraceous, consistency ceraceous.

Hyphal system monomitic. Hyphae 1.5-6 $\mu \mathrm{m}$ in diam., with medallion-shaped clamps, in subiculum rather loosely arranged, some inflated up to $7 \mu \mathrm{m}$ in diam., or with occasional secondary septa, in aculei rather densely arranged, thinwalled in subhymenium, thick-walled in trama; some core hyphae can penetrate the hymenium as ampullate pseudocystidia. Cystidia (gloeocystidia) weakly differentiated, utriform, 25-50 $\times 7-8 \mu \mathrm{m}$. Basidia clavate-pedunculate, $30-40 \times$ 5-8 $\mu \mathrm{m}$, 4-spored, with a basal clamp. Spores ellipsoid to short-cylindric, 7-10 ×5-6.5 $\mu \mathrm{m}$, with slightly thickened walls and oil-rich content, smooth, weakly cyanophilous, inamyloid.

Etymology: arbor - tree, fero - to bear; the name refers to the unusual configuration of the hymenophore, composed of arboriform or coralloid teeth.
The closest relative is Radulomyces molaris (Chaillet ex Fr.) M. P. Christ. which differs in having shorter (up to $2 \mathrm{~mm}$ long) unbranched aculei, more thin-walled core hyphae, and larger basidiospores $(9-11 \times 5.5-7 \mu \mathrm{m}$ according to Jülich \& Stalpers 1980 , or 8-13 × 6.5-8 $\mu \mathrm{m}$ according to Stalpers 1998), and in lacking gloeocystidia.

The thick-walled apices of ampullate pseudocystidia and the presence of gloeocystidia, as well as spore dimensions (mostly not overlapping those of $R$. molaris), confirm an independent status of $R$. arborifer. However, this species was probably known to the mycologists earlier, attributed to the Radulum rude complex. Nikolaeva (1961: 84) depicted thick-walled, ampullate, inflated hyphae in her figure of $R$. rude, but in diagnosis on p. 83 the hyphae are characterized as thin-walled. The spores of $R$. rude, according to Nikolaeva, vary between 7-13 × 6-9 $\mu \mathrm{m}$. Although they are wider than in Radulomyces arborifer, it is quite possible that the material of Nikolaeva included two or more species. Unfortunately, the numerous forms of $R$. rude described by Nikolaeva (1961: 85), in particular f. confluens Nikol., were not characterized microscopically and references to herbarium specimens are missing, too. 
Fig. 2. Radulomyces arborifer Malysheva \& Zmitr. sp. nova (LE 214706): A - section through tooth, B - basidia, C - gloeocystidium, D - spores, E - thick-walled tramal hyphae, F - generative hyphae.

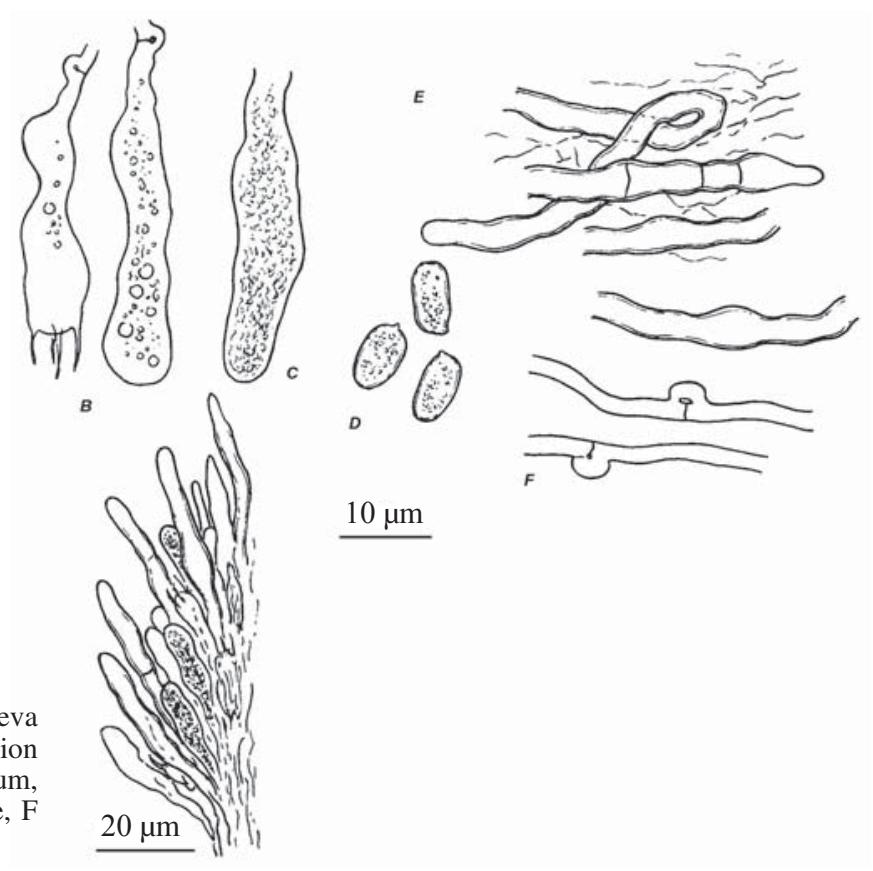

\section{Key to the hydnoid and raduloid Hyphodermataceae occuring in central parts of European Russia}

1. Spores thin-walled, cylindric, $\mathrm{Q} \geq 2.5$, hyphae with clamps

- Spores with slightly to distinctly thick wall, short-cylindric to broadly ellipsoid, $\mathrm{Q} \leq 2.5$, clamps present or absent

2. Leptocystidia moniliform, without septa or encrustation (genus Basidioradulum Nobles) ... - Leptocystidia or septocystidia fusoid, with sparse encrustation (genus Hyphoderma Wallr.)

3. On Syringa. Teeth confluent at their bases, after forming a poroid pattern, basidia 17-35 $\times$ 4-5 $\mu \mathrm{m}$, spores 7.5-9 $\times 2-3.5 \mu \mathrm{m}$ (Langer \& Dai 1998), slightly curved. - Basidioradulum syringae (E. Langer) Malysheva \& Zmitr. comb. nova (basionym: Hyphodontia syringae E. Langer in Langer \& Y.-C. Dai, Mycotaxon 67: 182, 1998). The species is known in Russia from Leningrad region only, growing on Syringa josikaea.

- On substrates other than Syringa, teeth separate

4. Aculei rather thin, solitary or in small clusters. Hyphae, basidia and spores with oil-rich content. Basidia 25-35 × 4.5-5.5 $\mu \mathrm{m}$, spores 6-7.5 × 2.5-3 $\mu \mathrm{m}$, cylindric. - Basidioradulum quercinum (Pers. : Fr.) H. Furuk., Bull. Gov. Forest. Exp. St. 261: 60, 1974.

- Aculei robust, anastomosing and forming crests or raduloid patterns. Hyphae, basidia and spores without oil globules. Basidia 22-30 × 4.5-6 $\mu \mathrm{m}$, spores 7-11 $\times 2-3 \mu \mathrm{m}$, clearly curved. - Basidioradulum radula (Fr. : Fr.) Nobles, Mycologia 59: 192, 1967.

5. Cystidia septate, 30-280 $\times 5.5-14 \mu \mathrm{m}$, cylindric. Basidia $25-45 \times 5-7 \mu \mathrm{m}$, spores $7-11 \times$ 3-4 $\mu \mathrm{m}(5.5-14 \times 2-5.5 \mu \mathrm{m}$ according to Yurchenko \& Zmitrovich 2001), usually slightly curved. - Hyphoderma cristulatum (Fr.) Donk, Fungus 27: 15, 1957 (= H. setigerum (Fr. : Fr.) Donk, 1957).

- Cystidia without septa, 30-120 × 5-10 $\mu \mathrm{m}$, fusoid, robust. Basidia 30-55 $\times 5-9 \mu \mathrm{m}$, spores $12-16 \times 3-4.5 \mu \mathrm{m}$, cylindric or weakly sigmoid. - Hyphoderma mutatum (Peck) Donk, Fungus 27: 15, 1957. 


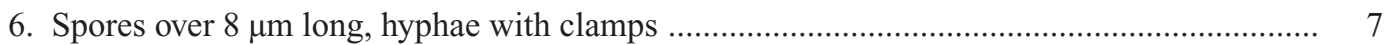

- Spores up to $8 \mu \mathrm{m}$ long, clamps present or absent ........................................................ 10

7. Basidia clavate-pedunculate, spores slightly thick-walled (genus Radulomyces M.P. Christ.) $\quad 8$ - Basidia utriform $(30-65 \times 6-8.5 \mu \mathrm{m})$, spores with strongly thickened wall, $8-11 \times 6-8$ $\mu \mathrm{m}$. - Hypochnicium bombycinum (Sommerf. : Fr.) J. Erikss., Symb. Bot. Upsalienses 16: $101,1958$.

8. Hymenophore tuberculate or almost smooth. Basidia 30-75 $\times 7-11 \mu \mathrm{m}$. Spores 7-11 $\times$ 6-8.5 $\mu \mathrm{m}$, broad ellipsoid. - Radulomyces confluens (Fr. : Fr.) M.P. Christ., Dansk Bot. Ark. 19: 230, 1960.

- Hymenophore toothed, basidia not over $50 \mu \mathrm{m}$ long

9. Teeth denroid or coralloid. Core hyphae thick- walled and bearing ampullate pseudocystidia. Gloeocystidia 25-50 × 7-8 $\mu \mathrm{m}$. Basidia 30-40 × 5-8 $\mu \mathrm{m}$. Spores 7-10 × 5-6.5 $\mu \mathrm{m}$, ellipsoid to short cylindric. - Radulomyces arborifer Malysheva \& Zmitr.

- Teeth unbranched or with broom-like tips; core hyphae thin-walled to slightly thickwalled. Gloeocystidia none. Basidia 35-46 × 6-8 $\mu \mathrm{m}$. Spores $8-13 \times 6.5-8 \mu \mathrm{m}$, broad ellipsoid to short cylindric. - Radulomyces molaris (Chaillet ex Fr.) M.P. Christ., Dansk Bot. Ark. 19: 232, 1960.

10. Without clamps. Basidia 20-40 × 5-5.5 $\mu \mathrm{m}$. Spores 5-6 $\times 4.5-5 \mu \mathrm{m}$, subglobose.

Radulodon casearius (Morgan) Ryvarden, Canadian J. Bot. 50: 2075, 1972. (The specimen reported as Radulum casearium (Morgan) Lloyd by Nikolaeva (1955) from Mordovsky Nature Reserve is Radulodon erikssonii Ryvarden. Nevertheless, this species may be found in European broadleaved forests).

- Clamps present.

11. On Malus. Hymenophore surface egg-yellow to yellow-orange. Subicum hyphae with abundant swellings (sclerocysts). Basidia 18-45 × 4-6 $\mu \mathrm{m}$. Spores 4.5-6 $\times 3-4.5 \mu \mathrm{m}$, broad ellipsoid. - Sarcodontia crocea (Schwein.) Kotlaba, Česká Mykol. 7: 117, 1953.

- On Populus. Hymenophore surface cream to pale-ochraceous. Subiculum hyphae without sclerocysts. Basidia 20-40 × 5-10 $\mu \mathrm{m}$. Spores 5-6.5 × 4.5-6 $\mu \mathrm{m}$, subglobose. - Radulodon erikssonii Ryvarden, Canadian J. Bot. 50: 2075, 1972.

Porotheleum fimbriatum (Pers.) Fr., Observ. Mycol.: 272, 1818. - Fig. 3, 4.

Basidiomata annual, resupinate, orbicular, then confluent up to $10 \mathrm{~cm}$ wide, with broad rhizomorphic margin. Hymenophore cyphelloid, at centre almost poroid (4-9 pores per $\mathrm{mm}$ ), cream to coffee brown, margin paler. Cups sessile, $0.2-0.8 \mathrm{~mm}$ in diam., of ceraceous consistency, united in a common subiculum, densely packed.

Hyphal system monomitic. Hyphae $1-3 \mu \mathrm{m}$ in diam., with clamps, in subhymenium thin-walled and strongly agglutinated, in subiculum loosely arranged, regularly branched or (in rhizomorphs) unbranched. Cystidia none. Basidia clavate, with a pronounced medial constriction, 17-22 × 4-6 $\mu \mathrm{m}, 4$-spored, with a basal clamp. Spores ellipsoid to short-cylindric, 3-6 $\times 1.5-2.5 \mu \mathrm{m}$, hyaline, with 1-3 globules, smooth, thin-walled, inamyloid.
Specimen examined: Russia. Zhiguli Nat. Res., on debris of Populus tremula in Acereto-Tilietum aegopodiosum, 25.VIII.2003 V. Malysheva \& I Zmitrovich (LE 214708).

This peculiar fungus is widespread but uncommon in Russia (Bondartseva \& Parmasto 1986). In Samara Region it is found for the first time.

The taxonomical position of this species is distant from the other aphyllophoroid fungi. Donk (1964) placed this genus in the family Schizophyllaceae Roze due to a polycyphelloid hymenophore. Further researches, however, have shown the heterogeneity of the cyphelloid group, and Porotheleum Fr. and Schizophyllum Fr. were mostly placed close to Merulius Fr. and Phlebia Fr., because they all have characteristic narrow cylindric basidia with expressed medial constriction (merulioid basidia). The circumscription of Schizophyllaceae has been rather enlarged (in- 


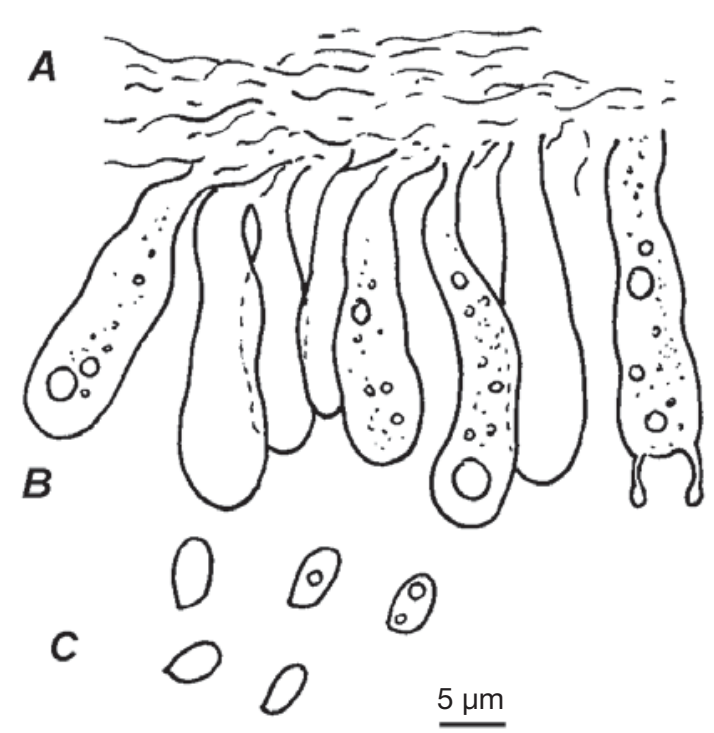

Fig. 3. Porotheleum fimbriatum (Pers.) Fr. (LE 214708): $\mathrm{A}$ - subhymenial hyphae, $\mathrm{B}$ - hymenium, $\mathrm{C}-$ spores.

cluding Meruliaceae Rea) - e.g. in "Nordic Macromycetes" (Hansen \& Knudsen 1997). However, the same type of basidia is characteristic of some other corticioid and agaricoid fungi. Basing only on this character, Porotheleum can be regrouped in different ways, while the other anatomical features make its position isolated. I am inclined to keep it in the family Porotheleaceae Murrill, together with the cyphelloid genera Calyptella Quél., Cellypha Donk, Henningsomyces O. Kuntze, and Stigmatolemma Kalchbr. (Cooke 1989).

Pilatoporus epileucinus (Pilát) Kotl. \& Pouzar, eská Mykol. 44: 231, 1990. - Fig. 5, 6.

Basidiomata annual, pilei sessile or slightly prostrate, $1-4 \times 0.5-3 \times 0.2-0.8 \mathrm{~cm}$, confluent to imbricate, in fresh condition fleshy-fibrous, then hard and fragile. Pileus surface initially velvety, then glabrous, cream to ochraceous-orange with obscure gelatinized zones, radially rimose. Margin up to $1 \mathrm{~mm}$ wide, sterile, rather acute, inrolled, slightly undulate, at first pale, later deep ochraceous, usually gelatinized. Context fibrous, at first cartilaginous, more or less hygrophanous, then of chalky consistency, cream-coloured to grayish. Hymenophore tubular. Tubes $1-5 \mathrm{~mm}$ long, cream-coloured, at first fleshy, then slightly gelatinized. Pore surface concolorous with tubes, pores rounded or elongated, rather thin-walled, 3-7 per mm.

Hyphal system trimitic-like. Generative hyphae 2-3.5 (4) $\mu \mathrm{m}$ in diam., with clamps, thin-walled, moderately branched, agglutinated in tube trama. Skeletal hyphae $2.5-7.5 \mu \mathrm{m}$ in diam., locally clamped and inflated, thick-walled (in $\mathrm{KOH}$ swollen), in context strongly branching ("binding hyphae"). Leptocystidia fusoid, 17-25 $\times 3-6 \mu \mathrm{m}$. Basidia 17-25 × 5-6.5 $\mu \mathrm{m}$, clavate, 4-spored, with a basal clamp. Spores 6-7.5 $\times$ 1.5-3 $\mu \mathrm{m}$, fusoid-cylindric, sometimes slightly amygdiform or allantoid, smooth, thin-walled or with slightly thickened wall, inamyloid, cyanophilous.

Associated with a brown rot.

Specimen examined: Russia. Zhiguli Nat. Res., on fallen Populus tremula in Acereto-Tilietum aegopodiosum, 22.VIII.2003 V. Malysheva \& I. Zmitrovich (LE 214709).

This species occurs in broadleaved forests of Europe and North America, and is found in Russia for the first time. It was described by Pilát as Leptoporus epileucinus from Ukraine growing on Fagus sylvatica. Kotlaba and Pouzar (1990) showed this species to be identical with the American Polyporus durescens Overholts. Overholts' species was validly published only in 1975 (Lowe 1975), and so Pilát's name has a priority.

The generic position of Leptoporus epileucinus Pilát is still unclear. Its placement in Fomitopsis P. Karst. (Gilbertson \& Ryvarden 1993) is rather problematic owing to highly specific hyphal system. Inclusion in Pilatoporus Kotl. \& Pouzar (1990) is more logical (see Vampola 1996). However, the latter genus is poorly differentiated from the monotypic genus Osteina Donk (1966). In my opinion, Pilatoporus should be considered as a synonym of Osteina.

The closest relatives of Pilatoporus epileucinus are the Mediterranean species P. ibericus (Melo \& Ryvarden) Kotl. \& Pouzar, and Antrodia bondartsevae Spirin, described recently from European Russia (Spirin 2002). These species are defined in the following key. 


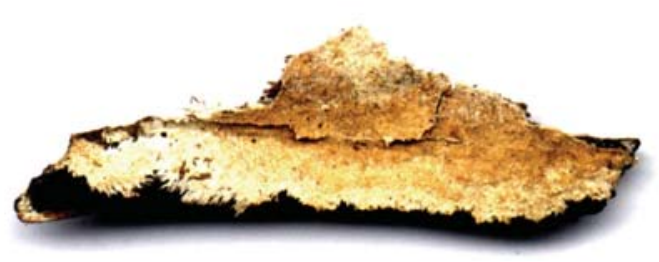

Fig. 4. Porotheleum fimbriatum (Pers.) Fr. (LE 214708): basidiome.

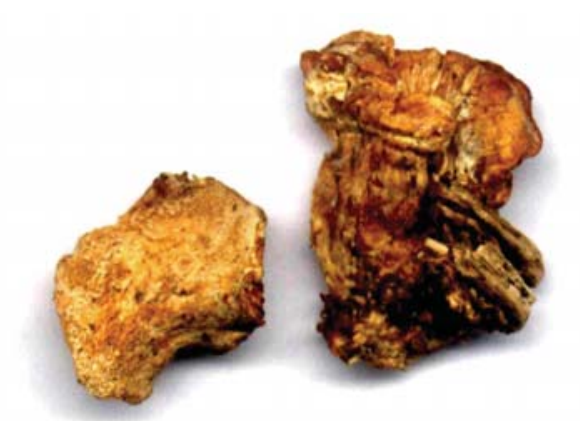

Fig. 5. Pilatoporus epileucinus (Pilát) Kotl. \& Pouzar (LE 214709): basidiome.

1. Pores 2-4 per $\mathrm{mm}$, spores $7-8.5 \times 2.8-3.5 \mu \mathrm{m}$, cylindric to slightly amygdaliform.

- Pilatoporus ibericus (Melo \& Ryvarden) Kotl. \& Pouzar, Cryptogamie Mycologie 14: 217, 1993.

- Pores 3-7 per mm, spores 4.5-7.5 × 1.5-3 $\mu \mathrm{m}$, allantoid or sigmoid

2. Spores $6-7.5 \times 2.2-2.8 \mu \mathrm{m}$. Gloeoplerous hyphae present in trama

- Antrodia bondartsevae Spirin, Mikol. Fitopat. 36: 33, 2002).

- Spores 4.5-7.5 × 1.5-3 $\mu \mathrm{m}$. Gloeoplerous hyphae absent. - Pilatoporus epileucinus (Pilát) Kotl. \& Pouzar

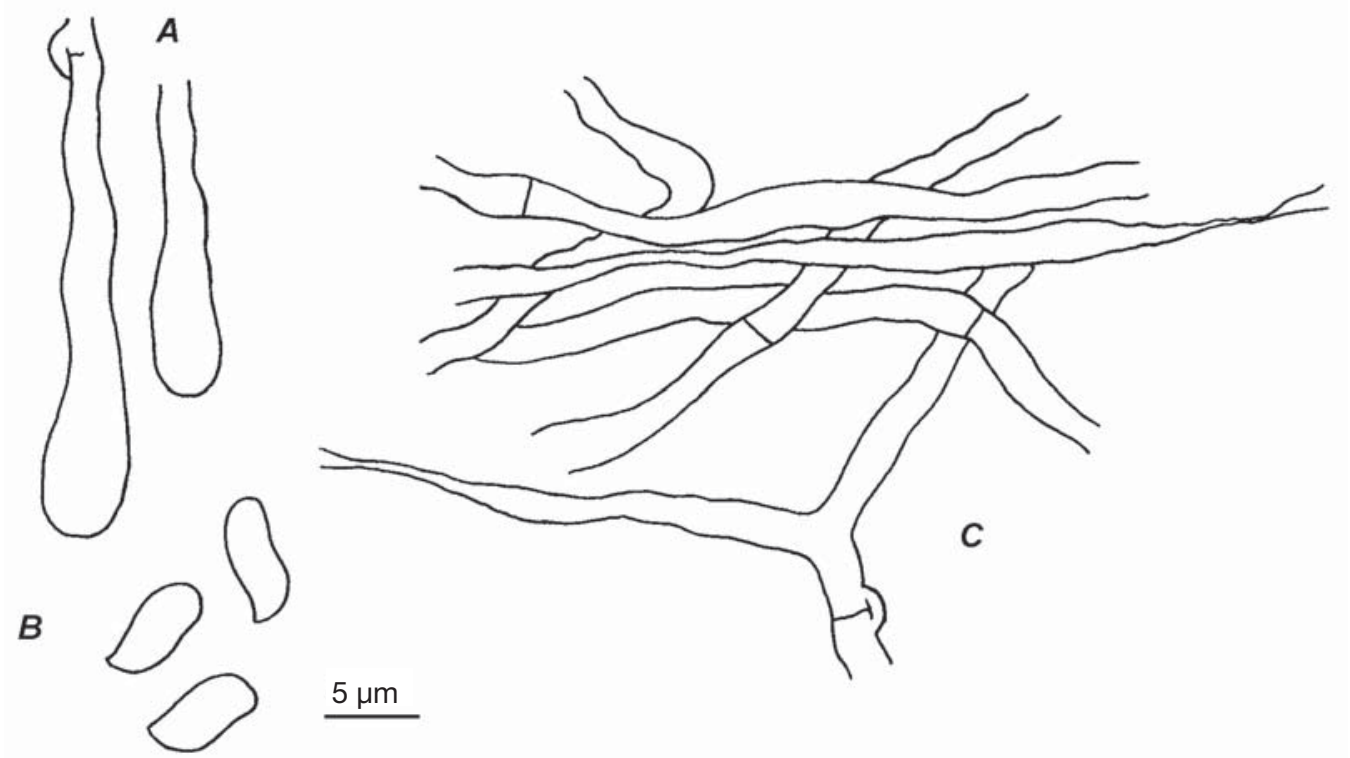

Fig. 6. Pilatoporus epileucinus (Pilát) Kotl. \& Pouzar (LE 214709): A - basidia, B - spores, C - hyphal structure of the context. 


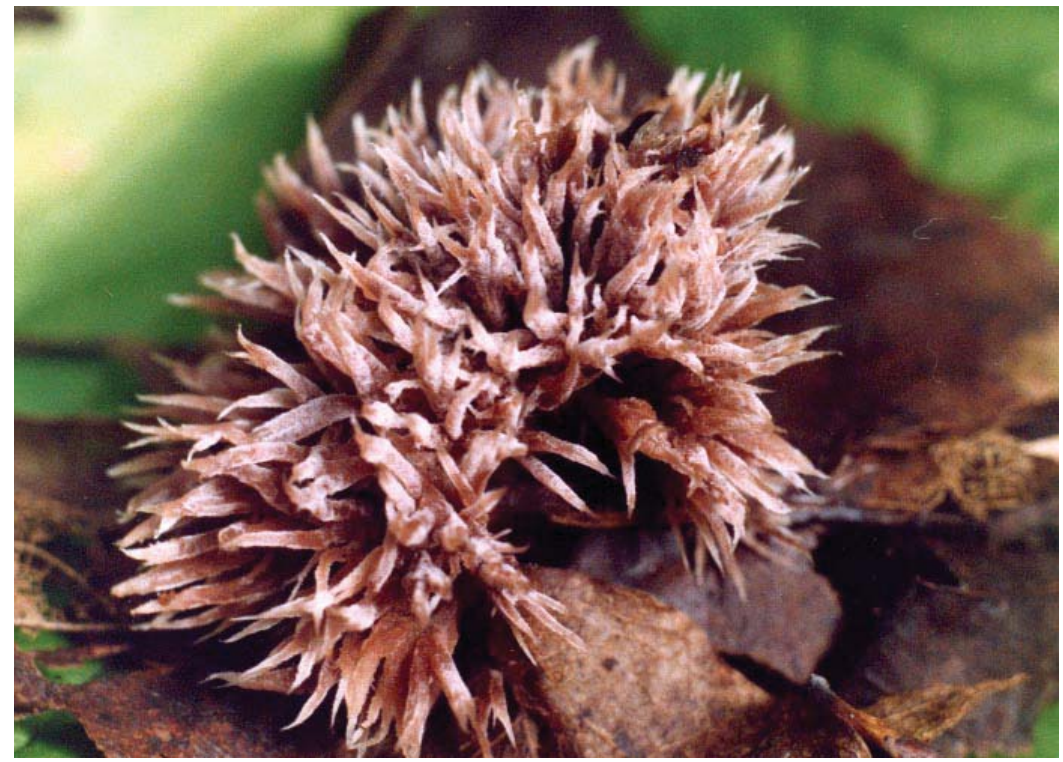

Fig. 7. Thelephora penicillata Fr. (LE 214707): basidiome.

Thelephora penicillata Fr., Syst. Mycol. 1: 434, 1821. - Fig. 7, 8.

Basidiomata annual, suberect or decumbent, subulate, ligulate, or spathulate, as a rule divided into cristate to penicillate lobes $0.5-1.5 \mathrm{~cm}$ wide, of membranaceous or ceraceous. Hymenium smooth to minutely tuberculate, fuscous purple, covering the whole surface or only the underside of the lobes. Flesh 1-2 mm thick, floccose. Odour indifferent.
Hyphal system monomitic. Hyphae 4-7 $\mu \mathrm{m}$ in diam., with clamps, hyaline or with yellowish contents; in subhymenium densely packed, agglutinated, rarely branched, thin-walled; in abhymenial surface loosely interwoven, regularly branched, thick-walled. Cystidia none. Basidia 35-50 × 7-10 $\mu \mathrm{m}$, utriculate, 4-spored, with a basal clamp. Spores 7-9.5 $\times 5-7 \mu \mathrm{m}$, lobed, triangular in outline, verrucose, with a central oildrop and yellowish contents, faintly cyanophilous, inamyloid; spore mass brown.
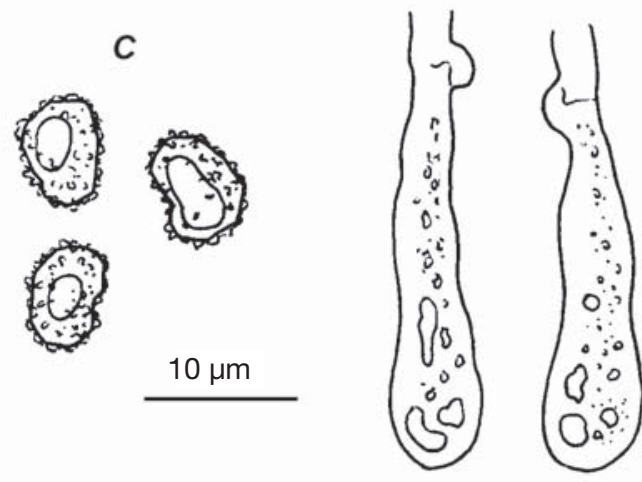

A

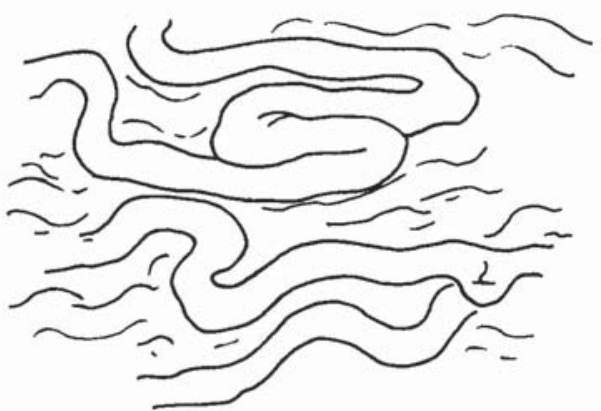

B

Fig. 8. Thelephora penicillata Fr. (LE 214707): A - hyphal structure of subhymenium, B - basidia, C - spores. 
Specimen examined: Russia. Zhiguli Nat. Res., on debris in Acereto-Tilietum aegopodiosum, 22.VIII.2003 V. Malysheva (20 finds, e.g. LE 214707).

This rare species of Thelephora Ehrh. : Fr. was reported from Russia by Zmitrovich (2000). The other specimens kept in LE and designated as $T$. penicillata represent the heterobasidiomycete Sebacina incrustans. This is the first report from Samara Region. In the study area this species is widespread in the gullies. Basidiomata develop on plant debris or bare soil. All finds were made in linden forests without pine.

The concept of the genus Thelephora was not discussed since Corner's monograph (1968), except the brief notice by Jülich \& Stalpers (1980), who stated that it is impossible to separate it from Tomentella Pat. If so, the priority should belong to Thelephora, which would lead in plenty of new combinations. This unwelcome fact may keep the taxonomists from uniting of these genera.

Acknowledgements: The author is very grateful to Tuomo Niemelä (Helsinki, Finland) and Ivan Zmitrovich and Wjacheslav Spirin (St. Petersburg, Russia) for a critical review of the manuscript and valuable help.

\section{References}

Bondartseva, M.A. \& Parmasto, E.H. 1986: Clavis diagnostica fungorum URSS. Ordo Aphyllophorales 1: Familiae Hymenochaetaceae, Lachnocladiaceae, Coniophoraceae, Schizophyllaceae. - Nauka, Leningrad. 192 pp. (in Russian).

Cooke, W. B. 1989: The cyphelloid fungi of Ohio. - Mem. New York Bot. Gard. 49: 158-172.

Corner, E. J. H. 1968: A monograph of Thelephora. - Beih. Nova Hedwigia 27: 1-110.
Donk, M. A. 1964: A conspectus of the families of Aphyllophorales. - Persoonia. 3(2): 199-324.

Donk, M. A. 1966: Osteina, a new genus of Polyporaceae. - Schweiz. Z. Pilzk. 6: 83-84.

Gilbertson, R.L. \& Ryvarden, L. 1986: North American polypores 1: Abortiporus - Lindtneria. - Fungiflora, Oslo. 433 pp.

Hansen, L. \& Knudsen, H. 1997: Nordic Macromycetes 3: Heterobasidioid, aphyllophoroid and gastromycetoid Basidiomycetes. - Nordsvamp, Copenhagen. 444 pp.

Jülich, W. \& Stalpers, J.A. 1980: The resupinate nonporoid Aphyllophorales of the Northern Hemisphere. - North-Holland Pub. Comp., Amsterdam etc. 335 pp.

Kotlaba, F. \& Pouzar, Z. 1990: Type studies of polypores described by A. Pilát 3. - eská Mykol. 44: 228-327.

Langer, E. \& Dai, Y.-C. 1998. Changbai wood-rotting fungi 8 . Hyphodontia syringae sp. nov. - Mycotaxon 67: 181-190.

Lowe, J.L. 1975: Polyporaceae of North America. The genus Tyromyces. - Mycotaxon 2: 1-82.

Nikolajeva, T.L. 1955: The occurence of Radulum casearium (Morgan) Lloyd in USSR. - Acta Inst. Bot. Acad. Sci. U.R.S.S. 10: 185-187 (in Russian).

Nikolaeva, T.L. 1961: Hydnaceae. Flora Plantarum Cryptogamarum U.R.S.S. 6. Izdatel'stvo Akademii Nauk SSSR, Moscow-Leningrad. 433 pp. (in Russian).

Spirin, W. 2002: A new species from the genus Antrodia. - Mikol. Fitopat. 36(4): 33-35 (in Russian).

Stalpers, J.A. 1998: On the genera Sarcodontia, Radulodon and Pseudolagarobasidium. - Folia Cryptog. Estonica 33: $133-138$.

Vampola, P. 1996: New localities of Pilatoporus ibericus in Europe and Asia. - Czech Mycol. 49: 85-90.

Yurchenko, E.O. \& Zmitrovich, I.V. 2001: Variability of Hyphoderma setigerum (Corticiaceae s.1., Basidiomycetes) in Belarus and northwest Russia. - Mycotaxon 78: 423-434.

Zmitrovich, I.V. 2000: New data on thelephoraceous fungi of Leningrad Region. - Mycology and Cryptogamic Botany in Russia: Traditions and Present day (Materials of conference): Pp. 128-131. - St. Petersburg (in Russian). 